\title{
Business performance model of herbal community enterprise in Thailand
}

\author{
Chayanan Kerdpitak ${ }^{\mathbf{a}^{*}}$
}

\begin{tabular}{|c|c|}
\hline A B S T RACT & \\
\hline $\begin{array}{l}\text { Article history: } \\
\text { Received December 12, } 2021 \\
\text { Received in revised format } \\
\text { December 30, } 2021 \\
\text { Accepted January } 192022 \\
\text { Available online } \\
\text { January } 202022 \\
\text { Keywords: } \\
\text { Business performance model } \\
\text { Herbal medicine } \\
\text { Herbal community enterprise }\end{array}$ & $\begin{array}{l}\text { The research study was carried out to investigate the actual business performance model in herbal } \\
\text { medicine business in Thailand. The conceptual framework was developed from resource-based } \\
\text { theory of herbal medicine community enterprise, and other contemporaneous research in herbal } \\
\text { medicine business performance. Accordingly, the study considered the importance of the factors } \\
\text { of marketing channel, competitive advantage, logistics integration and innovative management. In } \\
\text { this direction, the study employed a quantitative research approach. Questionnaire was used for } \\
\text { data collection. Data were collected from } 340 \text { entrepreneurs of herbal community enterprise. } \\
\text { Finally, data were analyzed using structural equation modeling (SEM) to examine the actual herbal } \\
\text { business performance of the organizations studied through all operational links in the marketing } \\
\text { channel, competitive advantage, logistics integration and innovative management. Results of the } \\
\text { study found that marketing channels had a positive effect on herbal business performance. } \\
\text { Competitive advantage also had a positive effect on herbal business performance. Furthermore, } \\
\text { logistics performance had a positive effect on herbal business performance. Finally, similar results } \\
\text { were found in case of innovative management which shows the positive effect on herbal business } \\
\text { performance. }\end{array}$ \\
\hline
\end{tabular}

C 2022 Growing Science Ltd. All rights reserved.

\section{Introduction}

In encouraging knowledge as well as local wisdom, producing revenue, and developing management capacities, "the 12th National Economic and Social Development Plan (BE 2560-2564)" remains to pay more attention to community economic development (CED) as a foundation towards self-sufficiency economic growth. The problem with CED and business adaptation is that entrepreneurs do not yet recognize the significance and worth of the spirit of a dynamic CEs, and only see CEs as a subject of the raw materials, manufacturing techniques, cost, as well as profit, which has an impact on organizational and societal integration. In addition, this will come to be a society adhered towards industry which utilized advantages as well as interest of those who are disadvantaged. This also comes to be a society of the consumption total of a materialism competition, through limited room for development collaboration. As a result, paradigm for innovative herbal CED must attempt to understand CED holistically, for the purpose of understand the nature of CE systematically, or to understand the technique that could be utilized as an instrument for developing the self-reliant system for making economic system of CEs by employing satisfactory economic theory (Wajirum \& Inwang, 2018).

Nonetheless, community enterprises for the herbal city in the North of Thailand are facing different problems regarding organizational performance. The organizational performance of the community enterprises for the herbal city is not sustainable (Fang et al., 2020; Mensah \& Gordon, 2020). There are many reasons due to which the organization performance of the enterprises is affected. Marketing innovation and market penetration are also the major reasons that directly influence the organization performance of community enterprises for the herbal city (Kharat, Chikhalkar, Jha, \& Kharat, 2020). According to the current study, where other factors affect organization performance, such as innovation management, logistics integration, marketing channel, and competitive advantage are also the major factors which directly affect the organization performance of community enterprises for the herbal community in Thailand.

* Corresponding author

E-mail address: chayanan.ke@ssru.ac.th (C. Kerdpitak)

(C) 2022 Growing Science Ltd. All rights reserved.

doi: $10.5267 /$ j.uscm.2022.1.004 
There is not a unified body of knowledge about business performance (Marr \& Schiuma, 2003). Researchers in the fields of strategy, operations, human resources, information systems, management accounting and reporting, and marketing are all contributing to the topic of performance assessment (Franco-Santos \& Bourne, 2005; Marr \& Schiuma, 2003; Neely, Adams, \& Kennerley, 2002). While multidisciplinary as well as diversified research is enticing, this could also lead to issues. Such various methods to performance assessment have resulted in a variety of definitions of the BPM system, with less consensus on its core components and attributes (Dumond, 1994).

Along with various previous consensus, evidence from the previous studies demonstrates that innovation management has significant impacts on the performance (Firman, Putra, Mustapa, Ilyas, \& Karim, 2020). Moreover, the results of prior studies also explore that Innovation management brings numerous results with it. Innovation also has a meaningful influence on the performance of an organization. Furthermore, it is also clear from the literature that product design in addition to packaging, product placement, and product promotion and pricing matters a lot among the customers and end- user of the product (Dubey et al., 2020). Hence, innovation management are vital elements with significant impacts on the organization performance of a firm. Along with innovation management also played a significant part to enhance an organization's performance. A number of earlier research has proven that competitive advantage has a positive as well as significant association with business performance (Maziriri, 2020; Wright, Kroll, Pray, \& Lado, 1995). In addition, the marketing channel had also described a positive as well as significant association with the business performance (Nuseira \& Aljumahb, 2020). Along with these indicators, the logistics integration had played an essential part to increase the performance. Various empirical evidence studies had found that logistics integration played an important role in increasing business performance (Le, Wang, \& Nguyen, 2020; Novais, Marín, \& Moyano-Fuentes, 2020). Along with these significance variables but previous study still had inconsistent findings because the results still have unclear findings. Moreover, the previous studies had a major focus on developed economies but had a little attention on developing economies like Thailand especially, herbal community enterprise in Thailand. Therefore, the core objective of the current study is to demonstrate the relationship of innovation management, competitive advantage, marketing channel, logistic integration on organization performance of herbal community enterprise in Thailand.

The study was divided into the following five sections, introduction, literature review, research methodology, data analysis, discussion, and conclusion. The limitations and future direction were also discussed at the end of the study.

\section{Literature review}

\subsection{Business performance}

Business performance is a multidimensional concept Murphy, Trailer, and Hill (1996) that can be departmental indicators such as production, finance or marketing or consequential indicators such as growth and profit (Ahn et al., 2016; Wolff \& Pett, 2006). Measuring it with objectives or subjective indicators (Dawes, 1999; Harris \& Ogbonna, 2001). This study took subjective performance measures adapted by Venkatraman and Walker (1989), due to difficulties in collecting hard financial data from private companies, in the absence of any target data which is publicly available and comprises companies in the sample (Priem, Rasheed, \& Kotulic, 1995; Zulkiffli, 2014). In relation to the respective competitors, the performative indicators suggested by Venkatraman and Walker (1989) measured performance.

\subsection{Marketing Channel and business performance}

The marketing channel (MC) could be described in place of as the number of outside entities which a company utilized for its distribution goals. A channel is essentially the route, pathway, or path by which products and valuables flow, moving from the manufacturer in the direction of the end product users (Valos \& Vocino, 2006). The variation of distribution always plays an important part for product flows from producers towards customers as well as for corporate effectiveness by the MC (interorganizational network of institutes consisting of agents, wholesalers as well as retailers). Thus, the performance of their channel institutions is becoming increasingly concerned for manufacturers (Morgan, 2012). Like other business areas, MC requires careful management, as superior management policies and strategies help an organization achieve a difference, on the other hand they are hard to double Brown, Lusch, and Nicholson (1995) at the same time. The management of the MC refers to the analysis, planning, organization and control process of the MC for an enterprise (Yang \& Kankanhalli, 2014). It is probably a Strategic Problem that has great importance for many manufacturers to manage a distribution channel. Channel management will dramatically affect the satisfaction and performance of the channel members, the customer satisfaction and the profitability of the company. The previous dialectic means that sales managers are increasingly focused on strategic problems when the organizational hierarchy is increasing. Thus, sales managers at higher organizations, rather than sales managers at lower organization's level, are more likely to take part in seven channel management decisions (discussed earlier). We have taken the classification categories typically used in literature into consideration the different hierarchical levels of sales management (e.g., Refs. (Cron \& Levy, 1984; Jia \& Wang, 2013; Pulendran, Speed, \& Widing, 2003). Specifically, the following hypotheses are posited:

$\mathbf{H}_{1}$ : The marketing channel has a significant relationship with the business performance. 


\subsection{Competitive advantage and business performance}

Existing literature discusses the advantages of having a competitive advantage, which allows a company to outperform its competitors. This study adds to the literature that the competitive advantage improves financial performance in companies (Moorman \& Slotegraaf, 1999). Common market performance indicators include customer satisfaction, product and services, customer retention and customer loyalty, whilst cost, sales income, profits and market shares are common indicators of financial performance (Moorman \& Slotegraaf, 1999). Companies with an innovation advantage offer their customers the latest and most innovative superior value products ( $\mathrm{Li}, \mathrm{Zhang}$, \& Chan, 2005). The larger value provided by the market providing, the more satisfied as well as committed the company's customers remain, and the greater the value, the more probably the marketing plan is of higher quality. (Anderson \& Zeithaml, 1984). Companies with market differentiation advantages, on the others, have positively generated exclusive images for its market products through tailoring its marketing combinations specifically towards its target clients (Miller, Spann, \& Lerner, 1991).

\section{H2: The competitive advantage has a significant relationship with the business performance.}

\subsection{Logistics integration and business performance}

As competition in the marketplace grows, organizations are compelled to focus on improving their internal operations as well as integrating suppliers and customers into the value chain processes. Much has been written about the importance of suppliers to their customers, resulting in the development of competitive capabilities (quality, delivery, flexibility, and cost). integrated flow of materials from suppliers creates a smooth manufacturing process (Frohlich \& Westbrook, 2001). Firms and suppliers are working in tandem in such a way that their respective activities are blurring (Stock, Greis, \& Kasarda, 2000). Logistics integration can greatly mitigate many of the negative impacts of logistics, like the bullwhip influence (Lee, Kwon, \& Severance, 2007; Randall et al., 2015). Lean production systems, with reliable order cycles and inventory reduction, are possible because of integrated logistics (Cagliano, Caniato, \& Spina, 2006; Sheel, Singh, \& Nath, 2019). Most corporations and their supply chain partners function as a single entity when integrating logistics. This benefits the entire supply chain (Jayaram \& Tan, 2010). There are different kinds of vertical integration, but in other words, vertical integration can produce these benefits for businesses: quality, dependability, planning and control, as well as lower costs (La Londe \& Masters, 1994). Several operational benefits can be derived from improved logistics integration, including lower costs, reduced lead time, and reduced risks. Additionally, improved logistics integration yields increased sales, distribution, customer services, and service levels as well as increased customer satisfaction (Kim, 2009). Research shows that integration has a positive influence on the performance of the supply chain (Van der Vaart \& Van Donk, 2008). The plants in the study by De Toni, Meneghetti, Nassimbeni, and Tonchia (1999) had advanced stages of the logistical interactions, and those studied by Frohlich and Westbrook (2001) were more extensively interconnected. The research of Cheng, Yang, and Sheu (2014) discovered that a greater degree of collaboration is a critical component in operational efficiency, and finally, the work of Y.H. Li, Huang, and Tsai (2009) found that increased supply chain integration correlates to supply chain performance. Thus, we can formulate our first hypotheses:

\section{H3: The logistics integration has a significant relationship with the business performance.}

\subsection{Innovation management and business performance}

This study's goal was to study the association among innovation and BP. Historically, it has been believed that new products that are introduced to the market face limited direct competition, resulting in greater profits for the firm. Companies that regularly introduce new products will, over time, see their profits diminish because of imitation and competition, but those that keep introducing new and innovative products may maintain their profits for an extended period (Sharma \& Lacey, 2004). Many other scholars argue that firms engage in innovation activities for a number of reasons, the most important of which is to increase the firm's success and performance. Oslo Manual also stresses the role of innovation activities in company performance (Inauen \& Schenker-Wicki, 2011). Innovation has received little study as it relates to company performance. The Oslo Manual (Inauen \& Schenker-Wicki, 2011) classification of innovation isn't used much in additional studies. This study was designed to make up for a knowledge gap in the field of vehicle design by exploring this possible connection in the Turkish automotive industry. According to Calantone, Harmancioglu, and Droge (2010), who studied the relationships between learning orientation, firm innovativeness, and firm performance in the U.S. manufacturing and service industries, the framework consists of a set of interconnected concepts. Innovativeness at a firm has a direct bearing on firm performance. To test their theory, researchers Cho and Pucik (2005) used structural equation modeling to examine the relationship between innovativeness, quality, growth, profitability, and market value at the firm level in the United States finance industry. The results of their study suggested that innovativeness is a strong indicator of long-term growth, and long-term growth is an excellent indicator of profitability. Based on previous discussions, the following hypothesis of the study had been formulated.

\section{$\mathbf{H}_{4}$ : Innovation management has a significant relationship with business performance.}

Based on previous discussion, the study framework of the study had been formulated below. 


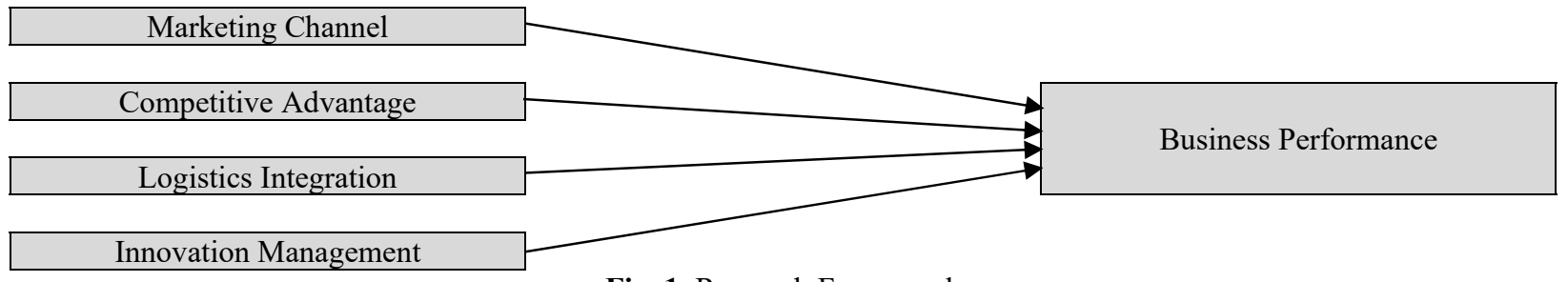

Fig. 1. Research Framework

\section{Research Methodology}

The current section had presented the methodology of the current study that had been implemented for the current study. The quantitative approach had applied for this study in which the positivism research approach had been used. It is explained in the extant literature that quantitative research approach is considered to be a more appropriate approach as compared to qualitative approach. Moreover, the current study had applied cross sectional research design. The data was collected from the employees of the herbal community enterprise that were highly qualified. The data was collected by using an online survey by using a google form because at the pandemic situation the respondents were unable to give the response face to face. The herbal community enterprise was selected because this industry is a big industry of Thailand that has a greater level of employment and contribution in the economic development. Therefore, this time the study on herbal community enterprise is important because this sector was also badly affected by the pandemic situation. The study is conducted by collecting the data primarily by using a questionnaire that had been adopted by the previous studies. The questionnaire of the current study had been adopted from the previous studies where this construct was already used. All the following items were measured on a five-point Likert Scale that is ranged 1 for strongly disagree and 5 for strongly agree. Total five hundred questionnaires were distributed to the target respondents. In total, 340 questionnaires were returned which shows a 68 percent response rate.

\subsection{Data Analysis}

The data was analyzed in the following two steps. Descriptive statistics and inferential statistics. The descriptive statistics was done by using SPSS software while inferential statistics was done by using an AMOS.

\subsection{Descriptive Statistics}

Descriptive analysis was carried out in the SPSS. Table 1 presents the descriptive analysis of each variable. The results of the analysis show the respondents' perception about the variables. The analysis was carried out on the means score of all the items. The mean scores for all the variables are ranged 3.90 to 4.34 . The mean scores for the above variables are highly moderated which shows that respondents are highly involved in the independent and dependent variables activities. In addition, the standard deviation (S.D) of all the variables are ranged from 0.54 to 0.72 . The mean score and S.D of all the variables are depicted in the following Table 1.

Table 1

Descriptive Statistics

\begin{tabular}{|c|c|c|c|c|c|c|c|c|c|}
\hline & Variable & Range & Min & Max & $\bar{x}$ & SD. & Variance & Sk & $\mathrm{Ku}$ \\
\hline \multirow{4}{*}{ Marketing Channel } & MAC1 & 2.90 & 2.72 & 5.00 & 4.20 & 0.57 & 0.33 & -0.08 & -0.78 \\
\hline & MAC2 & 2.95 & 2.00 & 5.00 & 4.08 & 0.59 & 0.34 & -0.28 & 0.35 \\
\hline & MAC3 & 3.00 & 2.20 & 5.00 & 4.05 & 0.65 & 0.43 & -0.26 & -0.44 \\
\hline & MAC4 & 3.00 & 2.00 & 5.00 & 3.90 & 0.72 & 0.53 & -0.67 & 0.51 \\
\hline \multirow{3}{*}{ Competitive } & COA1 & 2.95 & 2.10 & 5.00 & 4.15 & 0.62 & 0.39 & -0.34 & 0.12 \\
\hline & COA2 & 3.00 & 2.00 & 5.00 & 4.22 & 0.52 & 0.28 & -0.24 & 0.07 \\
\hline & $\mathrm{COA} 3$ & 2.65 & 2.85 & 5.00 & 4.18 & 0.50 & 0.26 & 0.21 & -0.38 \\
\hline \multirow{4}{*}{ Logistics Integration } & LOI1 & 3.00 & 2.00 & 5.00 & 4.16 & 0.65 & 0.44 & -0.44 & -0.29 \\
\hline & LOI2 & 3.00 & 2.10 & 5.00 & 4.23 & 0.64 & 0.41 & -0.61 & 0.25 \\
\hline & LOI3 & 2.90 & 2.30 & 5.00 & 4.34 & 0.56 & 0.33 & -0.62 & -0.17 \\
\hline & LOI4 & 2.40 & 2.60 & 5.00 & 4.33 & 0.54 & 0.30 & -0.27 & -0.71 \\
\hline \multirow{3}{*}{ Innovative } & INM1 & 2.85 & 2.65 & 5.00 & 4.17 & 0.54 & 0.29 & -0.16 & -0.19 \\
\hline & INM2 & 2.95 & 2.00 & 5.00 & 4.18 & 0.62 & 0.38 & -0.48 & 0.25 \\
\hline & INM3 & 3.00 & 2.00 & 5.00 & 4.06 & 0.71 & 0.51 & -0.93 & 1.08 \\
\hline \multirow{3}{*}{ Business Performance } & BUP1 & 3.00 & 2.00 & 5.00 & 3.91 & 0.72 & 0.51 & -0.73 & 0.71 \\
\hline & BUP2 & 2.90 & 2.10 & 5.00 & 4.15 & 0.58 & 0.35 & -0.41 & -0.24 \\
\hline & BUP3 & 2.70 & 2.50 & 5.00 & 4.19 & 0.54 & 0.29 & -0.29 & 0.09 \\
\hline
\end{tabular}

Note: $\mathrm{INM}=$ Innovative Management; $\mathrm{COA}=$ Competitive Advantage; MAC = Marketing Channel; LOI = Logistics Integration; BUP = Business Performance

\subsection{Inferential Statistics}

The data of the study had been analyzed by using a Structural Equation Modeling (SEM) technique through the AMOS software. This technique is more appropriate that had been already used in the previous studies. The analysis of the study has been used in two steps, one is measurement model and other one is structural model. These two models are explained below. 


\subsection{Measurement Model}

The reliability and validity of the construct is essential before the model assessment of the study (Hair, Sarstedt, Hopkins, \& Kuppelwieser, 2014). "For this purpose, firstly the researcher assessed the measurement model validity and discriminant validity. The following Table 1 has shown the findings of the measurement model. In the convergent validity, factor loading should always be greater than 0.5 which is required to establish the indicators' reliability. Moreover, the minimum required value for the Cronbach's alpha $>0.70$, composite reliability $(\mathrm{CR})>0.70$, and lastly average variance extracted $(\mathrm{AVE})>0.5$ (Hair, Hult, Ringle, \& Sarstedt, 2014). All these values are predicted in the following Table 2 that fulfills all these above discussed criteria.

Table 2

Factor Loadings. $(\mathrm{n}=340)$

\begin{tabular}{|c|c|c|c|c|c|c|}
\hline Variable & $\lambda$ & SE. & t-value & $\mathrm{R}^{2}$ & AVE & CR. \\
\hline Innovative Management & & & & & 0.686 & 0.865 \\
\hline INM1 (Parameter constants) & 0.81 & - & - & 0.82 & & \\
\hline INM2 & 0.96 & 0.04 & $18.452 * *$ & 0.71 & & \\
\hline INM3 & 0.66 & 0.05 & $13.986^{* *}$ & 0.52 & & \\
\hline Competitive Advantage & & & & & 0.751 & 0.900 \\
\hline COA1 (Parameter constants) & 0.83 & - & - & 0.84 & & \\
\hline $\mathrm{COA} 2$ & 0.90 & 0.04 & $21.427 * *$ & 0.71 & & \\
\hline COA3 & 0.80 & 0.05 & $19.990 * *$ & 0.71 & & \\
\hline Marketing Channel & & & & & 0.630 & 0.872 \\
\hline MAC1 (Parameter constants) & 0.85 & - & - & 0.47 & & \\
\hline MAC2 & 0.84 & 0.08 & $14.859 * *$ & 0.76 & & \\
\hline MAC3 & 0.92 & 0.10 & $14.233^{* *}$ & 0.83 & & \\
\hline MAC4 & 0.70 & 0.10 & $10.90 * *$ & 0.49 & & \\
\hline Logistics Integration & & & & & 0.615 & 0.863 \\
\hline LOI1 (Parameter constants) & 0.88 & - & - & 0.37 & & \\
\hline LOI2 & 0.97 & 0.13 & $10.744 * *$ & 0.71 & & \\
\hline LOI3 & 0.72 & 0.14 & $10.007 * *$ & 0.71 & & \\
\hline LOI4 & 0.50 & 0.18 & $9.964 * *$ & 0.69 & & \\
\hline Business Performance & & & & & 0.508 & 0.623 \\
\hline BUP1 (Parameter constants) & 0.56 & - & - & 0.31 & & \\
\hline BUP2 & 0.76 & 0.08 & $7.775 * *$ & 0.31 & & \\
\hline BUP3 & 0.75 & 0.08 & $7.877 * *$ & 0.46 & & \\
\hline
\end{tabular}

Note: INM = Innovative Management; COA = Competitive Advantage; MAC = Marketing Channel; LOI = Logistics Integration; BUP = Business Performance

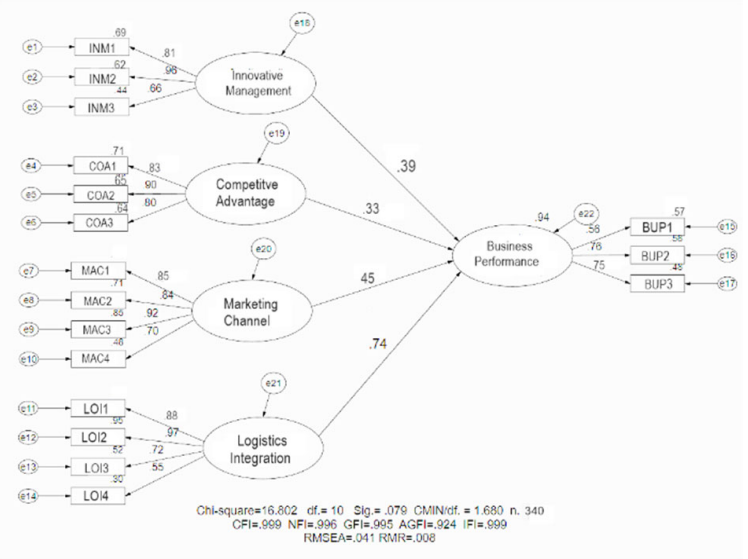

Note: $\mathrm{INM}=$ Innovative Management $\mathrm{COA}=$ Competitive Advantage; $\mathrm{MAC}=$ Marketing Channel; LOI = Logistics Integration; $\mathrm{BUP}=\mathrm{Business}$ Performance

Fig. 2. Business Performance Model for Herbal Medicine of Herbal Community Enterprise in Thailand

\section{Hypotheses Testing}

For hypothesis testing, the Structural Equation Modeling (SEM) technique has been applied by using an AMOS software. The research model consists of one dependent variable which is business performance. The Table 3 presented results confirm the significant direct relationship of Innovative management and business performance. These findings had shown that innovative management played an important role to increase the performance of the herbal community enterprise at the time of pandemic situation. While, the predicted results in Table. 3 further showed that competitive advantage also has a positive and significant relationship with the business performance. These findings had shown that competitive advantage is a significant variable that could affect business performance. The Table 3 predicted values are further shown that the marketing 
channel had also a significant and positive and significant relationship with the business (Morgan, 2012; Varadarajan, 2020) performance. The results further showed that the logistics integration is significantly and positively related with the business performance. These findings also show that these indicators are an important predictor to increase the business performance of herbal community enterprise in Thailand. These findings are further in line with previous studies who have same findings (Khoury \& Analoui, 2004; Leković, Strugar Jelača, \& Marić, 2019; Udriyah, Tham, \& Azam, 2019; Wijetunge, 2016; Wright et al., 1995). All of the following results are predicted in the following Table 3 below.

Table 3

Results of hypotheses testing

\begin{tabular}{|c|c|c|c|c|c|c|}
\hline & Var & & $\beta$ & SE. & t-value & Sig. \\
\hline Business Performance & $\leftarrow$ & Innovative Management & 0.39 & 0.07 & 4.998 & $0.000^{* *}$ \\
\hline Business Performance & $\leftarrow$ & Competitive Advantage & 0.33 & 0.06 & 5.788 & $0.000 * *$ \\
\hline Business Performance & $\leftarrow$ & Marketing Channel & 0.45 & 0.09 & 4.211 & $0.000 * *$ \\
\hline Business Performance & $\leftarrow$ & Logistics Integration & 0.74 & 0.04 & 23.649 & $0.000 * *$ \\
\hline
\end{tabular}

* Statistically significant 0.001

** Statistically significant 0.05

Note: IMM = Innovative Management; COA = Competitive Advantage; MAC = Marketing Channel; LOI = Logistics Integration; BUP = Business Performance

\section{Conclusion}

The research study was carried out to investigate the actual business performance model in herbal medicine business in Thailand. The conceptual framework was developed from the competitive advantage theory, resource-based theory of herbal medicine community enterprise, and other contemporaneous research in herbal medicine business performance. Accordingly, the study considered the importance of the factors of marketing channel, competitive advantage, logistics integration and innovative management. In this direction, this study employed a quantitative research approach. Questionnaire was used for data collection. Data were collected from 340 entrepreneurs of herbal community enterprise. Finally, data were analyzed using structural equation modeling (SEM) to examine the actual herbal business performance of the organizations studied through all operational links in the marketing channel, competitive advantage, logistics integration and innovative management. Results of the study found that marketing channels have a positive and significant effect on herbal business performance. Competitive advantage also has a positive and significant effect on herbal business performance. Furthermore, logistics performance has a positive and significant effect on herbal business performance. Finally, similar results were found in case of innovative management which shows the positive effect on herbal business performance. The findings of the current are further in line with previous studies who had also found the same results (Khoury \& Analoui, 2004; Leković, Strugar Jelača, \& Marić, 2019; Udriyah, Tham, \& Azam, 2019; Wijetunge, 2016; Wright et al., 1995). These findings had shown that these indicators are considered to be important predictors to increase the performance of the organization. As, all of the hypotheses of the study had been accepted. Therefore, this study had some practical and theoretical implications. Firstly, this study could provide help to the researchers for conducting their research in future. Secondly, this study could also provide a relationship among the researchers and industry, therefore in future this study could become a base for increasing the future area of research. Thirdly, this could also provide help to the policy makers to know about the importance of these indicators because the current study predictors are important predictors to increase the performance of the organizations. Fourthly, this study could also provide help to the owners and entrepreneurs to know about the importance of these indicators to increase their performance.

\section{Limitations and future directions}

Along with the significant contributions, the current study still had some limitations, namely: First, we are aware of the lack of numbers in this study sample because of the limitations of space and time between researchers, data collection activities, and the conditions experienced by business actors during the pandemic COVID 19. Second, the perspective of the growing literature on business performance predictors is very complex, so misperceptions from data collection activities will very likely occur. Thirdly, the study was limited on direct relationship while there are several other variables that can moderate or mediate among their relationship that could increase the research generalizability. Therefore, future research could be done along with the moderating or mediating variable. Fourthly, the study was limited cross sectional research design, therefore, future research could be done on longitudinal research design. Lastly, the study was limited to Thailand that is a developing nation, therefore, the research findings could not be generalized to developed economies. In this regard, future research could be done on developed economies to increase the research generalizability.

\section{References}

Ahn, J. M., Ju, Y., Moon, T. H., Minshall, T., Probert, D., Sohn, S. Y., \& Mortara, L. (2016). Beyond absorptive capacity in open innovation process: the relationships between openness, capacities and firm performance. Technology Analysis \& Strategic Management, 28(9), 1009-1028.

Anderson, C. R., \& Zeithaml, C. P. (1984). Stage of the product life cycle, business strategy, and business performance. Academy of management Journal, 27(1), 5-24.

Brown, J. R., Lusch, R. F., \& Nicholson, C. Y. (1995). Power and relationship commitment: their impact on marketing channel member performance. Journal of retailing, 71(4), 363-392. 
Cagliano, R., Caniato, F., \& Spina, G. (2006). The linkage between supply chain integration and manufacturing improvement programmes. International journal of operations \& production management, 26(3).

Calantone, R. J., Harmancioglu, N., \& Droge, C. (2010). Inconclusive innovation "returns": A meta-analysis of research on innovation in new product development. Journal of Product Innovation Management, 27(7), 1065-1081.

Cheng, C. C., Yang, C.-1., \& Sheu, C. (2014). The link between eco-innovation and business performance: a Taiwanese industry context. Journal of cleaner production, 64, 81-90.

Cho, H. J., \& Pucik, V. (2005). Relationship between innovativeness, quality, growth, profitability, and market value. Strategic management journal, 26(6), 555-575.

Cron, W. L., \& Levy, M. (1984). Participation in marketing channel functions and economic performance. International Journal of Physical Distribution \& Materials Management, 14(6), 17-33.

Dawes, J. (1999). The relationship between subjective and objective company performance measures in market orientation research: further empirical evidence. Marketing bulletin-department of marketing massey university, 10, 65-75.

De Toni, A. F., Meneghetti, A., Nassimbeni, G., \& Tonchia, S. (1999). Imprese artigiane e innovazione: Milano.

Dubey, R., Gunasekaran, A., Childe, S. J., Bryde, D. J., Giannakis, M., Foropon, C., . . . Hazen, B. T. (2020). Big data analytics and artificial intelligence pathway to operational performance under the effects of entrepreneurial orientation and environmental dynamism: A study of manufacturing organisations. International journal of production economics, $226,107599$.

Dumond, E. J. (1994). Making best use of performance measures and information. International journal of operations \& production management, 14(9), 16-31.

Fang, L., Xu, X., Li, J., Zheng, F., Li, M., Yan, J., . . Ma, G. (2020). Transcriptome analysis provides insights into the nonmethylated lignin synthesis in Paphiopedilum armeniacum seed. BMC genomics, 21(1), 1-15.

Firman, A., Putra, A. H. P. K., Mustapa, Z., Ilyas, G. B., \& Karim, K. (2020). Re-conceptualization of Business Model for Marketing Nowadays: Theory and Implications.

Franco-Santos*, M., \& Bourne, M. (2005). An examination of the literature relating to issues affecting how companies manage through measures. Production Planning \& Control, 16(2), 114-124.

Frohlich, M. T., \& Westbrook, R. (2001). Arcs of integration: an international study of supply chain strategies. Journal of Operations Management, 19(2), 185-200.

Harris, L. C., \& Ogbonna, E. (2001). Strategic human resource management, market orientation, and organizational performance. Journal of Business Research, 51(2), 157-166.

Inauen, M., \& Schenker-Wicki, A. (2011). The impact of outside-in open innovation on innovation performance. European journal of innovation management, 14(4), 496-520.

Jayaram, J., \& Tan, K.-C. (2010). Supply chain integration with third-party logistics providers. International journal of production economics, $125(2), 262-271$.

Jia, F. F., \& Wang, J. J. (2013). Marketing channel relationships in China: A review and integration with an institution-based perspective. Journal of Business Research, 66(12), 2545-2551.

Kharat, M. G., Chikhalkar, R. D., Jha, M. K., \& Kharat, M. G. (2020). Identification and ranking the significant factors influencing customer experience for shopping malls in the Indian context. International Journal of Indian Culture and Business Management, 21(3), 340-368.

Khoury, G. C., \& Analoui, F. (2004). Innovative management model for performance appraisal: the case of the Palestinian public universities. Management Research News, 27(1/2), 56-73.

Kim, S. W. (2009). An investigation on the direct and indirect effect of supply chain integration on firm performance. International journal of production economics, 119(2), 328-346.

La Londe, B. J., \& Masters, J. M. (1994). Emerging logistics strategies: blueprints for the next century. International journal of physical distribution \& logistics management, 24(7), 35-47.

Le, T.-M., Wang, C.-N., \& Nguyen, H.-K. (2020). Using the optimization algorithm to evaluate and predict the business performance of logistics companies-a case study in Vietnam. Applied Economics, 52(38), 4196-4212.

Lee, C. W., Kwon, I. W. G., \& Severance, D. (2007). Relationship between supply chain performance and degree of linkage among supplier, internal integration, and customer. Supply Chain Management: An International Journal.

Leković, B., Strugar Jelača, M., \& Marić, S. (2019). Importance of innovative management practice: solution for challenges in business environment and performance in large organizations in Serbia.

Li, H., Zhang, Y., \& Chan, T.-S. (2005). Entrepreneurial strategy making and performance in China's new technology ventures-the contingency effect of environments and firm competences. The Journal of High Technology Management Research, 16(1), 37-57.

Li, Y.-H., Huang, J.-W., \& Tsai, M.-T. (2009). Entrepreneurial orientation and firm performance: The role of knowledge creation process. Industrial Marketing Management, 38(4), 440-449.

Marr, B., \& Schiuma, G. (2003). Business performance measurement-past, present and future. Management Decision.

Maziriri, E. T. (2020). Green packaging and green advertising as precursors of competitive advantage and business performance among manufacturing small and medium enterprises in South Africa. Cogent Business \& Management, 7(1), 1719586

Mensah, A. M., \& Gordon, C. (2020). Strategic partnerships between universities and non-academic institutions for sustainability and innovation: Insights from the University of Ghana Sustainability Challenges in Sub-Saharan Africa I (pp. 245-278): Springer. 
Miller, A., Spann, M. S., \& Lerner, L. (1991). Competitive advantages in new corporate ventures: The impact of resource sharing and reporting level. Journal of business venturing, 6(5), 335-350.

Moorman, C., \& Slotegraaf, R. J. (1999). The contingency value of complementary capabilities in product development. Journal of Marketing Research, 36(2), 239-257.

Morgan, N. A. (2012). Marketing and business performance. Journal of the academy of marketing science, 40(1), $102-119$.

Murphy, G. B., Trailer, J. W., \& Hill, R. C. (1996). Measuring performance in entrepreneurship research. Journal of Business Research, 36(1), 15-23.

Neely, A. D., Adams, C., \& Kennerley, M. (2002). The performance prism: The scorecard for measuring and managing business success: Prentice Hall Financial Times London.

Novais, L., Marín, J. M. M., \& Moyano-Fuentes, J. (2020). Lean Production implementation, Cloud-Supported Logistics and Supply Chain Integration: interrelationships and effects on business performance. The International Journal of Logistics Management, 31(3), 629-663.

Nuseira, M. T., \& Aljumahb, A. (2020). The role of digital marketing in business performance with the moderating effect of environment factors among SMEs of UAE. International Journal of Innovation, Creativity and Change, 11(3), 310-324.

Priem, R. L., Rasheed, A. M., \& Kotulic, A. G. (1995). Rationality in strategic decision processes, environmental dynamism and firm performance. Journal of management, 21(5), 913-929.

Pulendran, S., Speed, R., \& Widing, R. E. (2003). Marketing planning, market orientation and business performance. European Journal of Marketing, 37(3/4), 476-497.

Randall, W. S., Hawkins, T. G., Haynie, J. J., Nowicki, D. R., Armenakis, A. A., \& Geary, S. R. (2015). Performance-based logistics and interfirm team processes: An empirical investigation. Journal of Business Logistics, 36(2), $212-230$.

Sharma, A., \& Lacey, N. (2004). Linking product development outcomes to market valuation of the firm: The case of the US pharmaceutical industry. Journal of Product Innovation Management, 21(5), 297-308.

Sheel, A., Singh, Y., \& Nath, V. (2019). Antecedents of logistics integration and firm performance for downstream petroleum supply chain. International Journal of Value Chain Management, 10(2), 141-161.

Stock, G. N., Greis, N. P., \& Kasarda, J. D. (2000). Enterprise logistics and supply chain structure: the role of fit. Journal of Operations Management, 18(5), 531-547.

Udriyah, U., Tham, J., \& Azam, S. (2019). The effects of market orientation and innovation on competitive advantage and business performance of textile SMEs. Management Science Letters, 9(9), 1419-1428.

Valos, M. J., \& Vocino, A. (2006). An integrative marketing channel performance measurement framework. Journal of Database Marketing \& Customer Strategy Management, 14(1), 17-28.

Van der Vaart, T., \& Van Donk, D. P. (2008). A critical review of survey-based research in supply chain integration. International journal of production economics, 111(1), 42-55.

Varadarajan, R. (2020). Customer information resources advantage, marketing strategy and business performance: A market resources based view. Industrial Marketing Management, 89, 89-97.

Venkatraman, N., \& Walker, G. (1989). Strategic consistency and business performance: Theory and analysis.

Wajirum, W., \& Inwang, K. (2018). Development of Business Strategies of Community Enterprise Entrepreneurs: A Case Study on Herbal Product Business in Lower Central Region 1. ABAC ODI Journal Vision. Action. Outcome, $5(1), 117$.

Wijetunge, W. (2016). Service quality, competitive advantage and business performance in service providing SMEs in Sri Lanka. International Journal of Scientific and Research Publications, 6(7), 720-728.

Wolff, J. A., \& Pett, T. L. (2006). Small-firm performance: modeling the role of product and process improvements. Journal of Small Business Management, 44(2), 268-284.

Wright, P., Kroll, M., Pray, B., \& Lado, A. (1995). Strategic orientations, competitive advantage, and business performance. Journal of Business Research, 33(2), 143-151.

Yang, Y., \& Kankanhalli, A. (2014). The impact of social media marketing on online small business performance.

Zulkiffli, S. N. A. (2014). Business performance for SMEs: Subjective or objective measures? Review of Integrative Business and Economics Research, 3(1), 371.

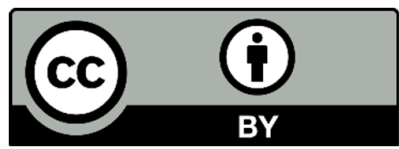

(C) 2022 by the authors; licensee Growing Science, Canada. This is an open access article distributed under the terms and conditions of the Creative Commons Attribution (CC-BY) license (http://creativecommons.org/licenses/by/4.0/). 